Published in a special issue of Women: A Cultural Review edited by Victoria Horne. DOI: $10.1080 / 09574042.2019 .1653118$

\title{
Heresies' Heresies: Collaboration and Dispute in a Feminist Publication on Art and Politics
}

Amy Tobin

\begin{abstract}
:
In the 1970s magazines, journals and periodicals constituted an alternative public sphere for second wave feminism. These publications provide an index - and at times the only documentation - of the activities of the women's art movement as well as its many iterations and divisions. This article addresses this imbalance, arguing that Heresies: A Feminist Publication on Art and Politics (1977-1992) was exemplar of the radical political challenge feminism posed to the art world and culture more broadly. Launched in 1977 by the Heresies mother collective, which included Joan Braderman, Mary Beth Edelson, Lucy R. Lippard, Harmony Hammond and May Stevens among others, the magazine had thematic issues edited by different collectives and comprised of material from an open call. Content ranged from poetry, to academic essays, to artworks both original and reproduced. This article considers the collaborative process of producing the magazine, which attempted to be inclusive, but in fact came to mirror the divisions - as well as political investments - of the broader women's movement, alongside the dissensus the publication provoked and attempted to confront.
\end{abstract}

The activist Ti-Grace Atkinson is once reported to have said that 'every revolution', including the Women's Liberation Movement, 'needed a mimeo machine'. (Brownmiller 1999: 67) The ability to make ad-hoc publications was a revolutionary leap in technology, and politically revolutionary in breaking open the limits of public discourse and print culture. The step into print, was a step into the distribution and control of information, dangerous, only its challenge to hegemony. (Fraser 1990) Newly-politicised women exploited this copier technology, circulating information about women and women's organising beyond the purview of the small group meetings that characterised the decentralised structure of the movement. Information sheets and newsletters, published fortnightly or monthly, were a practical means of organising by letting women know what was happening when, and what had already happened. These sheets soon began to include evaluations of events, then opinion pieces, then editors' remarks, then letters to the editor, features and quickly their page numbers mushroomed. For artists and artworks these ad hoc publications were a means of circulating information and reproductions of artworks that otherwise remained underexhibited and little-seen. Print provided a channel for connection and dialogue, and now looking back, this print provides an index of activism, of sisterhood and of conflict. 
The 'mimeo-revolution' provides a context for other, slicker manifestations of women's liberation print culture. The relative ease of the mimeo-machine - although far more labour intensive than reprographics today - meant that publications could be written, laid up and printed locally, and often by a single group, although they usually incorporated information from the wider movement, often with each issue produced by a different group of women. Mimeo publications were a collective exercise, both in the sense that they could be produced by a small group, and because editorship could move peripatetically between groups. This ethos was picked up and carried on in the magazines and journals that appeared mid-way through the decade. This essay concerns one of these magazines: Heresies: A Feminist Publication on Art and Politics, which emerged in New York in 1977 with four issues appearing each year until $1992 .{ }^{1}$ Heresies never looked or felt like a mimeo publication; it was perfect bound, typeset, and professionally printed and distributed in issues numbering in excess of one hundred pages. It was paid for by a combination of subscriptions and donations from supporters listed in the back of each issue, many drawn from affluent members of New York art world that was Heresies most immediate context. Content was translated to the page via paste-up and, in early issues at least, often resembled mimeo publications in design. But, it was the editorial process, which directly reproduced that of earlier mimeo publications, with the 'Issue Collective' producing each thematic issue, while the founding Heresies Collective managed its continuation. This dual collective structure was a considered choice, one that attempted to update an earlier unity between women that looked past difference, and instead organised to 'be a place where diversity can be articulated'. (no.1 1977: np) As a publication devoted to art and politics Heresies had the potential to create a space for artists, art critics and writers to come together where the physical spaces of institutions, and the pages of other art publications had failed. ${ }^{2}$ The potential was fulfilled, but not without conflict. I am interested here, in the theatre of collaborative and collective relations performed in the pages of Heresies.

\section{$\underline{\text { Art and Politics }}$}

The positioning of Heresies as a publication on 'art and politics' marks it out from other manifestations of the women's art movement. The Heresies collective was the idea of the

\footnotetext{
${ }^{1}$ All issues of Heresies are available as black and white scans on heresiesfilmproject.org. ${ }^{2}$ Sabra Moore (2016: 47-57), a contributor to Heresies from 1981 until 1992, described being excluded from another publication because they had already featured a woman artist in their last issue.
} 
artists Joyce Kozloff and Michelle Stuart. The pair, who were neighbours, alighted on the idea of a new publication for feminist art while at the laundrette. They set a date for a first meeting in Kozloff's loft and set a chain of word of mouth invitations off into the community. Once the collective had settled into a group of regular members, and decided to start the publication, the name Heresies was decided upon from a list compiled by each collective member. (Braderman 2009) The collective agreed on 'heresies' because it included the feminine pronoun 'her', as well as the intimation of dissenting, dangerous speech. The double significance contained both the continuing importance of organising together as women, and the transgressive effects of such organising. However, it was also portentous of the controversies and debates about feminist organising that would take place across its pages, some predicted, others not.

An openness to contestation as well as celebration was evident early on, even in the subtitle 'a feminist publication on art and politics', which alluded to both feminist politics, and the political debates within feminism. Indeed, many members of the founding collective were activists. Lucy R. Lippard, for instance, has inferred that the Heresies Collective formed c.1975 in a spirit of frustration, both with existing women's art organisations and with other activist art groups such as Artists Meeting for Cultural Change (AMCC). While Lippard found that the men in the latter group 'could not even change their own sexist speech habits' despite their radicalism, she was also itching to disrupt existing women's groups by organising around 'along broader cultural lines', which I take to mean, away from the question of exposure and recognition. (Lippard 1984: 25) The first issue editorial picked up this sensibility, declaiming that Heresies was not for 'advertising a new set of genius products just because they are made by women'. (no.1, 1977: np) The guidelines for authors noted that the magazine did not publish reviews of exhibitions, nor monographic features on contemporary artists, in other words two of the most conventional forms of art criticism. In this way the editors signalled a break with the symbiotic relationship between the critic and the dealer-curator that held up the art-world system. (Alloway 1972) This was to be an exploratory publication - in their words it was 'ideas-oriented' - less concerned with fixing meaning, or defining cultural practice, than recording and reflecting on the broader field of art and feminism. (no.1, 1977: np) Heresies broke with both mainstream art publications like Artforum and October, as well as with other specialist feminist magazines. It was more ambitious than the six-page bulletin publication Women Artists Newsletter produced by Judy Seigel and Cynthia Navaretta, less focused on criticism and reviews than art critic Cindy 
Nemser's controversial Feminist Art Journal and more challenging than the Brooklyn-based womanart, which Carrie Rickey (1993) has commented avoided publishing articles on divisive subjects in an attempt to bring women together. Further afield Heresies also marked a departure from the Los-Angeles based journal Chrysalis, which was associated with cultural feminism and celebrating the emergence of a separate woman's art, as is suggested by the idea of gestation and birth in its title.

The bright red cover of the first issue of Heresies telegraphed the left-leaning, if not the explicit socialist and Marxist, interests of some on the editorial collective. The very idea of a journal that brought together art and politics suggested a commitment to the material conditions of art production, and the possibility that art could help in the transformation of society. This position went some way beyond the celebration of women artist's work in contemporary publications, and from the women's liberation politics espoused by mainstream organisations, which were often more concerned with transforming the status of women within existing capitalist conditions. The content of the first issue foregrounded a more radical political position.

The first page of the publication was given over to the Heresies Collective editorial statement, which encompassed the broad viewpoints of the founding collective. 'We hope', it stated, 'that HERESIES will stimulate dialogue around radical political and esthetic theory, encourage the writing of the history of femina sapiens, and generate new creative energies among women'. (no.1 1977: np) The terminology and linguistic play speaks of diverse interests, which are later spelled out (no.1 1977: np):

Heresies is structured as a collective of feminists, some of whom are also socialists, Marxists, lesbian feminists or anarchists; our fields include painting, sculpture, writing, anthropology, literature, performance, art history, architecture and filmmaking.

\footnotetext{
${ }^{3}$ The statement is signed by Patsy Beckert, Joan Braderman, Mary Beth Edelson, Harmony Hammond, Elizabeth Hess, Joyce Kozloff, Arlene Ladden, Lippard, Mary Miss, Marty Pottenger, Miriam Schapiro, Joan Synder, Elke Solomon, Pat Steir, May Stevens, Michelle Stuart, Susana Torre, Elizabeth Weatherford, Sally Webster, and Nina Yankowtiz.
} 
After a photomontage against US imperialism in South-East Asia by the Australian artist Mandy Martin, another set of editorial statements appear. The scallop-edge border that surrounded the first, demarcates another collective text. Around it are a number of individual statements authored by the first issue collective - drawn from the founding Heresies Collective - comprising Joan Braderman, Harmony Hammond, Elizabeth Hess, Arlene Ladden, Lippard, and May Stevens. Their collective statement reads:

The editorial collective of this first issue of Heresies shares not a political line but a commitment to the development of coherent feminist theory in the context of practical work. The time for reformulating old positions or merely attacking sexism is past. Now we must take on the most problematic of feminist theory, esthetic theory and political theory. We are not only analysing our own oppression in order to put an end to it, but also exploring concrete ways of transforming society.

The individual statements articulate different political positions, but it is clear that the first issue collective shared an interest in a critical practice. Elizabeth Hess described them as the 'politicos' of the founding collective. (Braderman 2009) The selection of contributions further demonstrated the group's interest in left-leaning politics. Barbara Ehrenreich's article 'Toward Socialist Feminism' immediately followed the 'First Issue Collective Statement', with a section from Martha Rosler's post-card novel on the conditions of immigrant women labourers, Tijuana Maid, following that. Manifestos and reports from political groups like la Mujer Peruna and Wages for Housework were included along with articles on cultural activism, such as Carol Muske's article on writing classes for women in prison, while Black Panther Assata Shakur's polemic 'What is Left?' appeared toward the issue's end. Braderman and Lippard contributed articles on art and class, as well as a report on the Puerto Rican Day Parade, which related to Braderman's activism with the Puerto Rican community in New York. The first issue also included international contributions, including from the Italian feminist collective Rivolta Femminile, and a selection of posters for the People's Republic of China - an inclusion that signals the interest in Communist China on the Left in the West. While the collective left the question of the relationship between feminism, art and politics open, as well as the relationships between these diverse political positions and contexts, the first issue was far from neutral in its advocacy of a leftist feminism, in some ways it was a manifesto. 


\section{The Editorial Collective}

The second issue of Heresies registered the effects of the first, listing a much-altered editorial collective, and including a selection of letters in a section titled 'From The Readers'. The letters published offer both affirmation and critique. The poet Adrienne Rich, who was also published in the first issue, questioned the publication of an advertisement for the Leftist and to her mind sexist - publication Seven Days, which Hess was a contributor to, and criticised the implication that 'feminism and politics are two different things', as was implied in an illustration of the three graces, two dressed in dungarees, in an advertisement for Heresies. Remarks from the artists Leslies Sills and Joan Mathews discussed the affirmation they felt from articles by Lippard and Hammond, while a long statement from the New York Movement Women's Caucus (1977: 125) took issue with Heresies' leftism. They called out the publication as 'a pseudo-sophisticated development of consciousness-raising groups', presumably a comment on its open call editorial structure, and interrogated the collective's political credentials:

Who is your audience?

Are you trying to cross class lines?

(Can any art journal cross class lines?)

Are you trying to popularise feminism while advertising women's art?

Does uniting art and politics politicise your art by creating a politicised context?

What is your "politicised" community?

Are you proselytising a "catch all" feminism because you're unable to define and support a unified stance?...

Does Heresies use politics opportunistically?

The response of the Movement Women's Caucus is symptomatic of a committed leftistfeminism, with a deep suspicion of the political potential of art. Nonetheless the statement makes some salient points about the efficacy of Heresies' democratic, non-aligned status; what could an art publication do in the context of a political movement? Artists had been at the service of political publications already through the decade - the publication of Rosler's Vietnam photo-collages in Goodbye to All That: Newspaper for San Diego Women is one of the most famous examples - but there had never been a dedicated site to explore the politics 
of feminist art-making that avowedly sought to go beyond advocacy. ${ }^{4}$ Heresies was this site. It could publish political imagery, along with political fiction or poetry, while also pushing against the boundaries of what was considered art, and who could be an artist. As the letters from the women artists attest, it allowed women to think about their art practice expansively, beyond the 'patriarchal economic monolith that dominates the art world'. (NY Movement 1977: 125) Far from 'proselytising a “catch all” feminism', Heresies provided a meeting point for many different, often conflicting feminisms. The publication of this response to the first issue registers the collectives' commitment to criticism. On the page, the questions levelled at the publication, become open questions for all its readers to consider.

The collective built criticism into the process of producing Heresies. Following the publication of each issue, the issue collective held an open meeting at the New York women's cooperative gallery A.I.R. and later at Martha Wilson's space Franklin Furnace. The meetings offered the opportunity for those based in New York to offer feedback and make demands, they functioned as a supplement to the other collectives who ran and produced the magazine and demystified the process. (Braderman 2009) The meetings were only one of the ways in which Heresies sought to be open and inclusive. Contributions were solicited by open calls, with the future issues listed in the back page of every issue, inviting the reader to become a contributor. Like many other women's groups, the collective supported women's practical and creative development by sharing skills and learning new techniques together - a mode of working that was closely linked to worker education. Collective members would rotate roles, enabling the knowledge of the means of production to be passed on and building confidence. The make up of the issue collective would change with each issue, including those from the established Collective, and women otherwise external to the magazine interested in each particular theme. (Moore 2016: 50) This issue collective would then be split into different groups: editorial and design/production, with $\mathrm{Su}$ Friedrich pasting up each issue. This was a contingent, flexible and sometimes difficult, way of working. In the minutes from a 1976 meeting, the Collective articulate the importance of defining the 'process' of collective work, of making decisions together, and particularly of taking responsibility for decisions made. They note: 'we need to clarify what we as a

\footnotetext{
${ }^{4}$ See Martha Rosler, Tron (Amputee), Goodbye to All That, no.3, 1970 and Vacation Getaway in Goodbye to All That, no.10, 1971.
} 
Collective endorse as processes. How are we going to go about our business of putting out a publication and working as a Collective?' (Heresies Collective in Robinson 2001: 88-89)

In practice the collective structure led to a shifting, mutable publication. The theme of each issue allowed different interests to surface and be gathered together into something more like an anthology than a magazine. Yet rather than make its preceding issue obsolete, the serial quality of the magazine meant that diverse and sometimes, antagonistic topics were put into conversation. The open attitude to the design of each issue, and the avoidance of regular contributors, columns or features gave agency to each issue-collective, and marked a departure from the regulated content of other publications. These organisational structures were important for a number reasons, not only opening up the magazine to diverse ideas about feminism, art and politics, but also challenging the hierarchical structure of the usual magazine masthead, and as such articulating a model for a feminism, and feminist-informed art, beyond the cult of the individual.

The collective process was not, however, always an efficient way of producing of a publication. Skills sharing meant that each stage of production took time, and because the collective changed with each issue, so a new group of women had to be trained. The selection of material was also laborious; contributions from each open call could be read and commented upon by every editor. In Joan Braderman's documentary The Heretics, collective members recall the long, intense weekly meetings, during which the group would try to find consensus. Clearly this was no easy thing, as Harmony Hammond describes, the group developed different 'ground rules' to try and balance the very different characters in the group. A number of issues of Heresies were themed around the practicalities and politics of organising as women. Within the first three years issue two 'Patterns of Communication and Space Among Women', issue seven 'Women Working Together' and issue nine 'Organised Women Divided', all traced modes of connection, space making, co-existence, trust and political division. The difficulty of collective work was a hot topic both for those involved in making the magazine and for their readers. Many feminist collectives struggled with conflict, and many women struggled to articulate their relationship to the movement especially as it rubbed up against other responsibilities or identifications. But while other organisations concealed conflict, in Heresies problems of unity and solidarity were played out. 
Almost every issue of Heresies contains instances of dissensus, with the question of class and elitism particularly pervasive as issue one and its critiques attest. Nonetheless it was the 'Lesbian Art and Artists' (no.3, 1977), 'Third World Women' (no.8, 1978) and 'Racism is the Issue' (no.12, 1982) editions of Heresies that exposed some of the deepest rifts. These rifts paralleled those in the larger movement, and were magnified in the magazine by the hierarchical, dual collective structure of the magazine. To distinguish from each issue collective, the founding collective was quickly renamed the Mother Collective, and it took on a parental capacity commenting on the selection, and design of each issue, as well as providing support and ensuring the publication carried on. Unlike the conventional editorial board, the Collective did not have editorial control, particularly as content was drawn from an open call. In the context of 1970s feminism, the name reverberates with associations: from leftist interests in the mother and housewife as political subjects, to the reclamation of the association between procreation and creativity in cultural feminism. In any case Heresies was a matriarchy, with a unique, if hierarchical structure. (Freeman 1972) When members of the Mother Collective joined an issue collective, they brought their knowledge and status with them and likewise when these members attended Mother collective meetings, they brought a commitment to their issues of the magazine. In the case of the Lesbian Art and Artists issue, the conflict of interest between the two collectives developed into division.

The collective editorial statement of Heresies no. 3 emphasised the difficulty of organising as a lesbian in a feminist organisation. The issue collective members, Cynthia Carr, Betsy Crowell, Betsy Damon, Rose Fichternoltz, Louise Fishman, Su Freidrich, Harmony Hammond, Marty Pottenger, Amy Sillman, Christine Wade and Kathy Webster stated (vol.1, no.3 1977: np):

This issue of Heresies arises out of our need to challenge the heritage of secrecy, silence, and isolation which has been a necessity for lesbians who make art. Because we have no recognizable community with a sense of history, we seek to begin one by affirming and making visible the excellence of our efforts. As lesbians, we choose to create an issue devoted exclusively to work by lesbians in the context of a feminist publication... Because of our position within a predominantly heterosexual feminist journal, we had to struggle against the desire to make the definitive lesbian art issue. 
The collective statement emphasises the political necessity of making lesbians visible against the violence of historical erasure, but also notes the difficulty of existing 'within' a 'hetereosexual feminist journal', which threatens the erasure of its lesbian membership. There were numerous other publications devoted to lesbian life and experience such as Dyke Quarterly (1975-9) and Sinister Wisdom (1976-ongoing), which were advertised in this issue of Heresies and Azalea: A Magazine by Third World Lesbians (1977-83), which was not, nonetheless the Lesbian Art and Artists issue of Heresies was a threshold moment, 'an intervention in dominant discourses of the day', as Tara Burke (2013) has put it, when heterosexual feminists overlooked, and excluded lesbians. For the Issue Collective this edition of Heresies was about asserting the presence of lesbians within heterosexual culture, and their concomitant erasure, because they were seen to be within that culture, rather than active members, defining the cultural field. As such the editorial collective were wary of tokenism, and that this issue would grant the Mother Collective the excuse to decentre the coverage of lesbian women in subsequent issues of Heresies. The problem was whether to open the issue to all women, offering a shared responsibility for thinking about lesbian art and artists, or whether to limit the contributors to other lesbians. The latter was a problem because many women had not come out of the closet, or were concerned about being publicly outed. Many articles in the issue comment on the stories of women artists that could not be included because those women never came out. However, there was also a clear necessity to closing the call to non-lesbians. A number of women's testimonies in the magazine comment on difficult experiences within the women's movement. In Louise Fishman's (1977: 15) 'The Tapes' one anonymous woman describes the absence of support, or even acknowledgement from other feminists. She writes: 'I came out publicly about five years ago, at a Women's Ad Hoc Committee meeting. There was no comment from anyone there. It was as if I'd sneezed'. While in her article 'Class Notes', Hammond (1977: 35) writes that:

Heterosexual women get their privilege from the same patriarchal systems that give privilege to middle and upper class women. Coming out as a lesbian with a feminist consciousness forced me to realise what class privilege I did and did not have, and what I would now lose. Even the fact that I first came out to myself through my art and not in bed is in itself a reflection of my class position. As a feminist artist I had learned to use my work as a place to confront fears and other feelings privately in my studio. A woman working as a maid, a waitress, or a seamstress, does not have this option. 
The lesbian-only policy of the Lesbian Art and Artists collective was controversial with the Mother Collective, who saw it as separatist and exclusionary. Nonetheless the issue did not show a united front, there was an openness to exploring the difference of lesbian experience and to debate over the coherency of the term lesbian. Mother Collective and issue collective member Marty Pottenger (vol.1, no.3 1977: 2-3) stated it clearly in her individual statement:

I am not a lesbian. I make love only with women. I am in every way what society calls a lesbian. I will call myself and insist upon being called a lesbian as long as something called a heterosexual and a bisexual exists. In all probability, I am referring to a sexuality that will never exist inside of me... While believing that "heterosexual" and "lesbian" are concepts that directly serve to oppress us all, I know full well that as a lesbian I am intentionally persecuted and isolated by this society. The nearest weapon to me with which to fight back is the taking of the concept and the word lesbian and claiming it as my own. My continuing to work on this issue is the result of that conclusion.

The issue included a number of different contributions, including reprints of historical accounts, photographs of lesbians and presumed lesbians, a portfolio of work by lesbian artists, a transcript of a group discussion between lesbian artists, responses from women about what it means to them to be lesbian, along with numerous articles and poems on lesbian history, imagery and experience. The mix of contemporary and historical texts in the magazine emphasised the continuing importance of circulating and recirculating accounts of lesbian experience, written by lesbians. This enthusiasm for unearthing and claiming fragments of history foreshadows the work of queer theory later in the 1980s and 1990s. For issue three the editorial collective tested the limits of the guidelines for contributors including monographic texts on older women like the photographer Alice Austen, and accounts by contemporary artists and filmmakers like Louise Fishman (who was on the issue collective) and Barbara Hammer on their own work. 'Lesbian Art and Artists' was conceived of as a resource against the invisibility of lesbians in the mainstream art world, and in the predominantly heterosexual women's movement. 
The far-reaching accounts of lesbian experience in issue 3 were to be the subject of critique in the next of issue of Heresies. Below the 'The Next Issues of Heresies' call out in issue four was a statement addressed to the 'Lesbian Issue Collective' from the Combahee River Collective, and one in response. ${ }^{5}$ Attesting to the historical significance of Heresies itself, the Combahee River Collective Statement read (no.4 1978: np):

\begin{abstract}
We appreciate all the work the Lesbian Art and Artists issue of HERESIES represents. We find it appalling, however, that a hundred years from now it will be possible for women to conclude that in 1977 there were no practicing Black and other Third World lesbian artists.
\end{abstract}

The statement (no.4 1978: np) goes on to insist that this absence cannot be explained by the whiteness of the issue collective, citing the caveat in the collective editorial statement: 'It is not sufficient to explain such grievous omissions merely by stating: “. . yet biases which informed our choices of material were certainly conditioned by the fact that we are all lesbians, white college-educated, and mostly middle-class women who live in New York and have a background in the Arts." Feminist and lesbian politics and creativity are not the exclusive property of white women.' The response includes an acknowledgement of the 'only too typical' effect of an 'all-white group operating in a racist society' and an admission of the larger problem of the whiteness of the Mother Collective (no.4 1978: np). The statement also invites proposals for an issue of Heresies about and produced by Third World women, outright asking the Combahee River Collective to pitch. The Issue Collective's response ends with their desire to "extend our publication to speak for many feminists who have not been well represented so far', and 'encourage a greater effort on the part of both HERESIES editorial collective and Third World women to enter into an exchange'. Suffice it to say that even in this spirit of generosity the collective still describe the publication in terms of ownership. It is 'our publication', which will 'speak for' more feminists. This language highlights one of the problems of a structure that tries to be capacious. Despite a desire for diversity and inclusivity, Heresies had its roots in a predominantly white, predominantly heterosexual feminism, no matter its expansion it was always going to have begun from that

\footnotetext{
${ }^{5}$ The Combahee River Collective comprised: founders Barbara and Beverly Smith, author of the 1977 Collective Statement Demita Frazier, and Sharon Bourke, Gloria Akasha Hull, Eleanor Johnson, Audre Lorde, Chirlane McCray, and Margo Okazawa Rey. These statements were reprinted in Morris and Hockley (2017: 176-183).
} 
more central, more conventionally powerful place. That the publication was open call and collectively-run - many women of colour were published in its pages, and eventually did join the collectives - Heresies did not introduce diversity into the core of the organisation, and as such it could not change the fact that difference was marginal.

The Boston-based Combahee River Collective never took up the invitation. While this may have been because they were primarily 'committed to working on struggles in which race, sex, and class are simultaneous factors in oppression' and therefore not art and culture, it was also surely that they had begun to 'publicly address... racism in the white women's movement', as their 'A Black Feminist Statement' of 1977 attests. (Morris and Hockley 2017: 182) The labour of understanding and combatting racism was not their labour, as they write in the Statement: 'Eliminating racism in the white women's movement is by definition work for white women to do, but we will continue to speak to and demand accountability on this issue.' The point is important, because it demonstrates the complacency of the antihierarchical, collective structure of Heresies. An egalitarian structure did not automatically result in openness and diversity, and sometimes could gloss over the deeper divisions.

Below the exchange between Combahee River Collective and the Lesbian Issue Collective in issue no.4 of Heresies was an announcement for volunteer editors for an issue on Third World Women. The Third World Women: Politics of Being Other issue appeared as number 8 in 1979. The collective included Lula Mae Blocton, Yvonne Flowers, Valerie Harris, Zarina Hashmi, Virginia Jarmillo. Dawn Russell and Naeemah Shabazz. In a recent text Aruna D'Souza (2018: 73-96) traces the context behind the designation 'third world' ${ }^{6}$ She describes it as 'a set of theorisations that aligned the political goals of black feminists in the United States with a worldwide struggle for decolonisation that cut through lines of class, gender and race', and locates it as a precursor to Kimberlé Crenshaw's now more widely-used 'intersectional feminism'. Importantly, third world feminism in North America was transnational in outlook and connected with international struggles against colonisation and imperialism. As D'Souza (2018: 76) notes in her quotation of the editorial for the journal Triple Jeopardy: Racism, Imperialism, Sexism, there was a necessity for third world people to strike imperialism in the 'belly of the beast', although artists like Zarina Hashmi, known as

\footnotetext{
${ }^{6}$ See also Catherine Morris, 'Struggling for Diversity in Heresies', in Hockley and Morris (2017: 184-7).
} 
Zarina, also disputed American women's identification with their counterparts in economically underdeveloped countries. The Third World Women issue of Heresies included a number of articles and artworks that engaged with the 'politics of other' as shaped by race, class, sexuality and gender, in the US and beyond. Articles dealt with immigration, incarceration, family, racism in the art world, Japanese internment, desire, homophobia and even dentistry. Artworks were published in the 'Other Portfolio' along with those by Beverley Buchanan, Ana Mendieta, Howardena Pindell and Adrian Piper through the magazine, while Valerie Harris contributed a series of three 'Power Exchanges' in which she dialogued with the filmmaker Chris Choy, the actress and writer Barbara Ann Teer and the artist and activist Camille Billops about creating political art, and surviving as a woman of colour in creative practice. There were some overlaps with other issues of Heresies though. As if echoing the posters in the first issue, the painter Vivian E. Browne submitted 'A Photo Essay on the People's Republic of China' that detailed the lives of women workers in documentary style.

Notably the editorial statement speaks of both the joy and difficulty of producing issue 8 . In the remarkably open joint statement they acknowledge (vol.2, no.4 1979: 1):

It was frightening when we spoke of not always understanding each other, nor trusting each other, and valuing different ideas and ways of being. With all the sameness of our double racial/ sexual oppression, our differences frequently did get in the way... We still do not always understand each other in terms of who our cultures, lifestyles and oppressions have made us be. But in working together we had to acknowledge the personal power inherent in who we are.

This issue collective was the first that did not include a member of the Mother Collective, and the editorial statement candidly recounts the difficulties of working with them. It is important to quote it at length:

Another issue that plagued us throughout the year and a half was our relationship with the Heresies collective. It vacillated from our being vaguely aware of their presence while we were engrossed in our work, to reactions of anger and suspicion because of unclear or double messages that we felt were racist and paternalistic... Communications were frequently awkward, 
confusing and presumptuous. Some writers, artists and activists would not submit their work, viewing the Heresies collective as racist and feeling the collective was using us, making no real efforts and issues without any consultation with us, it was enraging and exploitative. We found ourselves without the resources, organisations, connections or the finances to do anything about it. Too often we had to come to a reassessment of why we were here in the first place.

That the women had to reassess their 'place' in Heresies is suggestive of the limits to this otherwise mutable publication. Despite being reproducible, accessible and mobile, the magazine was another kind of institution, which some women, more than others, struggled to exist within. The statement is important for listing the conditions - implicit and explicit racism, access to resources - that were not broken down by collective organising.

While issue 8 saw editorship of an issue handed over to women of colour, none of the collective went onto join the Mother Collective, and it wasn't until issue 15 that Heresies directly confronted racism in the magazine. The Racism is the Issue Collective included black, Latina and white women, all of whom engaged with the racism in the women's liberation movement, in white women's understanding of Black Feminist struggle, and in the art world. ${ }^{7}$ For this issue, the collective did not publish a joint statement, but instead registered their difference and collaboration by publishing a section from a transcript of a taped conversation. The remarks of women of colour are candid. Carole Gregory and Hattie Gossett (no. 15, 1982: np) both remarked that after the collective editorial statement in the 'Third World Women' Issue many women saw the Mother Collective as a 'group of racist white women'. Issue 15 did not resolve the problem or the tension - the editorial collective statement in issue 16 remarks on the 'lack of outreach to Third World and Black communities' - but 'The Racism is the Issue' clearly started a conversation and got closer to the awareness the Combahee River Collective had sought to provoke. The issue included discussion of racism from white women and women of colour, as well as articles on racism between community groups including a piece by the poet and artist Cecilia Vicuña on

\footnotetext{
${ }^{7}$ The Heresies: Racism is the Issue collective were Vivian E. Browne, Cynthia Carr, Michele Godwin, Hattie Gossett, Carole Gregory, Sue Heinemann, Lucy R Lippard, May Stevens, Cecilia Vicuña and Sylvia Witts Vitale.
} 
indigenous women in Chile. ${ }^{8}$ As Cynthia Carr (no. 15 1982: np) notes in the 'Editorial Statement': 'If racism is going to change, I think what we did here will be a tool for that change. What I discovered was just that simple step- that you don't just say “Oh its all so horrible", but that you can do something about it.'

\section{Reading Heresies Now}

This essay serves as an introduction to some of the points of tension and conflict that animated Heresies in the 1970s and early 1980s. The issues I alighted upon represent some of the boldest attempts to constitute, critique and reconstitute a feminist collective practice. These examples align the production of Heresies with similar disputes in the broader women's art and women's liberation movements. While we could take this as testament to the contemporaneity of the journal, to its value as a record of feminist art politics, it is also worth remembering that the centrality of white, heterosexual women's concerns had been raised (long) before these journal issues were developed. For instance, Lippard had been a co-organiser of the Ad Hoc Protests at the Whitney in 1970 with Faith Ringgold, where they had called for $50 \%$ representation of women artists and artists of colour in the then Whitney Annual. Although Lippard was a consistent supporter of artists of colour, how was this originary moment of activism eclipsed in Heresies' foundation? Indeed, why was the inclusion of lesbian artists in the Mother collective not enough to set the agenda for giving lesbian artists the support they needed to explore their sexuality in their work and in history? Arguably the same support that all women artists had received to explore gender in their work and in art history in earlier years. Why did the openness of the open call, not feed into a more open collective structure? While we could answer some of these questions with practical responses of expediency, responsibility and trust, they also lead to a larger concern: why did feminist collective practice depend on operative similarity rather than solidarity?

And, what about reading Heresies now? Looking through the pages of Heresies, as I have done in a much-condensed way in this essay, is to look back on disputes between women, as well as on their creative experiments and political commitments. The women involved in Heresies were rebellious daughters, breaking with the public discourse of their parent print cultures. The magazine was heretical to the mainstream in its distribution of other stories of

\footnotetext{
${ }^{8}$ Cecilia Vicuña, 'Choosing the Feather', translated by Lorraine O'Grady, Heresies: Racism is the Issue, 15, 1982: pp.18-19.
} 
creative practice, but it was also heretical within the women's liberation movement. The magazine remains a valuable resource for the study of feminist creative work; it records lost and obscure artworks, includes texts by important and little-known figures, and provides a record of feminist print and graphic design practice. But unlike many other feminist publications, the various contributors and collective-members who produced Heresies pushed at fractures and divisions, not solely to expose those most vulnerable but also to open those with power to critique. The dissensus that punctuates the magazine is an important record of the failures and the difficulty of white, heterosexual women to open up the women's art movement, and the women's liberation movement, to difference. As the many voices published in its pages attest: diversity is not just about inclusion; tokenism is as painful as exclusion and must be overcome; deeper interrogations of the structures of value, of prejudice and guilt are necessary; and white women must acknowledge and look to surrender their own power and privilege. Perhaps this is the most important, and the most heretical, legacy of Heresies.

\section{Works Cited}

Alloway, Lawrence (1972). 'Network: The Art World Described as a System', Artforum, vol.11, no.1.

Braderman, Joan dir. (2009). The Heretics. colour, 91 mins.

Brownmiller, Susan (1999). In Our Time: Memoir of a Revolution, New York: Delta.

Burk, Tara (2013). 'In Pursuit of the Unspeakable: Heresies' "Lesbian Art and Artists" Issue, 1977', WSQ: Women's studies Quarterly, vol.41, nos. 3\&4, Fall/Winter, pp.63-78.

D’Souza, Aruna (2018). 'Early Intersections: The work of Third World Feminism', in We Wanted a Revolution Black Radical Women, 1965-85: New Perspectives, New York: The New Museums, pp. 73-96.

Fishman, Louise (1977) 'The Tapes', Heresies: A Feminist Publication on Art and Politics, 'Lesbian Art and Artists', vol.1, no.3, pp.15-21.

Fraser, Nancy (1990). 'Rethinking the Public Sphere: A Contribution to the Critique of Actually Existing Democracy', Social Text, no. 25/26: pp.56-80.

Freeman, Joreen (Jo) (1972), 'The Tyranny of Structurelessness', The Second Wave, vol.2, no.1.

Hammond, Harmony (1977). 'Class Notes', Heresies: A Feminist Publication on Art and Politics, 'Lesbian Art and Artists', vol.1, no.3, pp.34-36. 
Lippard, Lucy R (1984). Get the Message: A Decade of Art For Social Change. New York: E.P. Dutton.

Moore, Sabra (2016). Openings: A Memoir of the Women's Art Movement, New York City 1970-1992, New Village Press: New York.

Morris, Catherine and Rujeko Hockley, eds. (2017). We Wanted a Revolution Black Radical Women 1965-85: A Sourcebook. New York: Brooklyn Museum.

New York Movement Women's Caucus (1977). 'Do you see Feminism Correcting the Errors of Socialism?', Heresies, no.2.

Rickey, Carrie (1993). 'Writing (and Righting) Wrongs: Feminist Art Publications' in The Power of Feminist Art, edited by Mary D. Garrard and Norma Broude, New York: EP Dutton.

Robinson, Hilary ed. (2001). Feminism Art Theory: An Anthology 1968-2000, Oxford: Wiley Blackwell. 